\title{
Black Female Earnings and Income Volatility
}

\author{
Bradley L. Hardy \\ Department of Public Administration \& Policy \\ American University
}

May 2011

* Address correspondence to Bradley L. Hardy, Department of Public Administration and Policy, American University, 4400 Massachusetts Avenue NW, Washington, DC 20016; Email: bradley.hardy@gmail.com. I thank Richard Burkhauser and Jeff Larrimore for generously providing their data on consistent top-codes in the CPS. 


\begin{abstract}
I provide new evidence on earnings and income volatility of Black women in the United States over the past four decades by using matched data from the March Current Population Survey. I use a measure of total volatility constructed by Ziliak, Hardy, and Bollinger (2011) that encompasses both permanent and transitory instability, and that admits labor-force transitions. My results show that, for Black women, earnings volatility fell over the entire period and income volatility rose after the mid 1980's. I also find that changes over time in labor force transitions into and out of work along with an increasing share of Black women continuously employed coincide with shifts in volatility levels and trends. Among Black women, differences in volatility levels emerge across education groups and marital status, though the trends typically remain consistent.
\end{abstract}


America's labor market fundamentals have undergone significant structural change over the past 40 years (Autor, Katz, and Kearney 2008). Within this time frame, the early 1970s marks the realization of legal victories protecting women and minorities from labor market discrimination (Griggs v. Duke Power Co. 1971; Betsey 1994), which ultimately support an increase in labor force participation among women and Black Americans. The increased labor force participation of women coincides with a decline in their aggregate earnings volatility (Ziliak, Hardy, and Bollinger 2011 - hereafter referred to as ZHB), likely related to women transitioning into and maintaining stable employment. Still, in spite of their unique history and experience in the labor force (Conrad 2001), little is known about the earnings and income volatility experienced by Black women. In a departure from most volatility studies, the focus of this paper is on earnings and income volatility among Black women. I find average earnings and income volatility levels among Black women higher than those among White women and the overall population.

A combination of short-term and longer term factors may drive these differences in volatility levels, including differential exposure to economic risk from temporary job loss or cross-race differences in the economic consequences of skill biased technological change (Gottschalk and Moffitt 2009). People who can effectively borrow against economic volatility may feel little, if any, effects. However, when credit markets function imperfectly, individuals and families cannot adequately consumption smooth over permanent income (Loury 1981; Mazumder 2005). Without full insurance for volatility from unanticipated events, Black women exposed to higher earnings or income instability may experience a wide range of consequences affecting current needs and future investments. For example, volatility may compromise the ability of individuals to invest in themselves, their children's education (Becker and Tomes 1979; Blundell, Pistaferri, and Preston 2005; Keys 2008; Hardy 2010), and their own personal relationships (Chaney and Marsh 2009). Efforts to insure against downward economic volatility within the family can negatively impact wealth accumulation for relatives providing insurance and absorbing financial risks (Chiteji and Hamilton 2002). Thus, it is apparent volatility exposure could have serious consequences.

By documenting income and earnings volatility, it is possible to compare how trends in the volatility of non-labor income sources, including public assistance, respond relative to earnings volatility over time. By definition, income volatility focuses on the instability of labor market earnings, non-labor income, and government transfers. Yet, within the definition of income and among low to moderate income women, where U.S. social policies are targeted, earnings are typically the largest component. Using the March Current Population Survey (CPS) from 1973-2009 and leaning heavily on ZHB, the large sub-group sample sizes compared to the widely used Panel Study of Income Dynamics (PSID) allow for new evidence on earnings and income volatility among Black women. While labor force participation is increasing since the 1970s for all women, Blacks have lower employment levels relative to Whites over most of the sample period. I find declining earnings volatility of 10 percent for Black women and 16 percent among White women, coinciding with the rate of increase in female labor force participation by race. Black women exit the labor force at a slightly higher rate than White women over this time period, and the exclusion of labor force transitions results in lower volatility levels as well as volatility trends that are more closely aligned for women across race in the 1990s and 2000s. Between 1973 and 2009, income volatility falls, but within this series a rise is observed after the 1980s. This could be caused by a combination of market volatility for investment income and policy changes to means-tested government transfer programs. 


\section{Data}

I use data from the 1973-2009 waves (1972-2008 calendar years) of the March Annual Social and Economic Study of the CPS. The unit of observation is an individual between the ages of 16 and 60. Given the rotating design of the CPS, a respondent is in sample for 4 months, out 8 months, and in another 4 months, making it possible to match approximately one-half of the sample from one March interview to the next.

There was a major survey redesign both in the mid 1980s and mid 1990s so it is not possible to match across the 1985-1986 waves and the 1995-1996 waves. In addition, the line number, which is intended to uniquely identify a person in the household, was not recorded for the 1976-1978 survey years, and in 1977 there were changes in the format of matching variables. This yields an interrupted time series across 36 years with gaps in calendar years 1974-1975, 1975-1976, 1984-1985, and 1994-1995. See ZHB for a more detailed description of the match process and data generating procedure.

\section{Employment Trends of Black Women}

In figures 1 and 2, I plot employment trends for women continuously working $(1,1)$, entering the labor force $(0,1)$, exiting the labor force $(1,0)$, and never working $(0,0)$. The left columns of figures 1 and 2 show employment trends by race, and the right columns disaggregate employment by race and education. In 1973, approximately 50 percent of Black and White females work continuously. From this point forward, the labor force participation of White females rises consistently until the early 1990s, where it plateaus around 70 percent. Meanwhile, between 45 and 50 percent of Black females are continuously employed through the middle of the 1980s. At this point, more Black women enter the labor force and their participation converges towards that of White women. In the late 1990s, 65 percent of Black women work continuously. This level, like that of White females, falls in the 2000s to 60 percent for Blacks and 65 percent for Whites. The employment growth rate among White females, 36 percent, outpaces that of Black females, 16 percent. This slower employment growth rate among Black women coincides with a slower decline in earnings volatility over the past four decades. Between one-fourth and one-third of Black females do not work, and 12 to 20 percent of Black women transition into and out of the labor force.

[Figure 1 here] [Figure 2 here]

The right side panel of figure 1 depicts employment trends among Black and White women with less than high school education. Large differences in employment trends within race by educational attainment are apparent. For Black women, the proportion continuously working $(1,1)$ begins at approximately 40 percent and falls to 30 percent by the end of the sample period, while the share never working increases over the same period. Employment trends for White women with less than high school education follow the same trend, though the upward trend in never working $(0,0)$ and downward trend in continuously working $(1,1)$ women occurs later in the sample, around the late 1990 's. Transitions into $(0,1)$ and out of work $(0,1)$ are roughly similar across the four panels. This suggests differences in employment transitions are unable to fully explain differences in volatility across education groups. In figure 2, the right side panels depict employment trends among women with more than high school education. As expected, women with higher labor market skills display higher rates of continuous $(1,1)$ employment across race, between 70 and 80 percent, and below 20 percent are out of work both periods $(0,0)$. The employment trends across figures 1 and 2 show similar employment trends 
across Black and White females, and that skills are associated with higher levels of continuous employment. Considering these volatility trends and then comparing differences in educational attainment by race, table 1 shows almost one-third of Black females and 18 percent of white females lack a high school diploma. A 10 percent gap in favor of White females also emerges for post-high school educational attainment. Thus, it appears cross-race differences in educational attainment drive at least some of the observed difference in employment between Black and White females.

\section{[Table 1 here]}

\section{Trends in Earnings and Income Volatility Among Black Women}

From ZHB, earnings and income volatility are measured as the standard deviation of the arc percent change.

$$
\text { volatility }=\sqrt{\operatorname{Var}\left\{100 * \frac{y_{i t}-y_{i t-1}}{\bar{y}_{\imath}}\right\}},
$$

where $y_{i t}$ is earnings (income) for person $i$ in time $t$, and $\overline{y_{l}}=\frac{y_{i t}+y_{i t-1}}{2}$, which is the personspecific time mean across the matched pair of years (Dynan, et al. 2008). The key advantage of this measure over the variance of log earnings used in most of the prior literature is that it is defined even if earnings are zero in one of the two years, and that it is symmetric and bounded below by -200 percent and above by +200 percent. ${ }^{1}$ With a rising share of the population out of the labor force two years in a row after the mid 1990s among women, my definition retains these individuals and sets their volatility to zero. This definition captures volatility from short-term events, such as temporary unemployment spells, along with permanent shifts or structural change in the economy (Gottschalk and Moffitt 1994; Keys 2008; Dynan et al. 2008; ZHB).

\section{[Figure 3 here]}

Figure 3 depicts trends in year-to-year individual earnings and income volatility for Black and White females. The top left panel, earnings volatility of workers in all states of employment follows a steady downward trend for women between 1973 and the mid-1980s, falling 10 percent among Black women, at which time the trend levels off. Across race, the trends follow the same pattern, though volatility levels are higher for Black females from the mid-1980s onward. By 1986, most of the decline in earnings volatility is realized for Black and White women. White women experience a larger 16 percent overall decline in earnings volatility over the period. ${ }^{2}$

In the top right panel of figure 3, before-tax income volatility trends for Black and White women follow the same upward trajectory from the middle of the 1980s onward. While volatility of income falls for both Black and White women between the early 1970s and 1980s, a steady rise follows between 1986 and 2008. The year-to-year variability among Black women lies within the range of White women's volatility throughout the approximately 25 year period

\footnotetext{
${ }^{1}$ The symmetry property is violated if earnings are negative one year, say due to a business loss, and positive the next. In this analysis, I do not allow for negative earnings. There are a small number of negative observations, between zero and six, in any given year. In ZHB, the arithmetic mean in the denominator is modified so that $\bar{y}_{l}=\frac{a b s\left(y_{i t}\right)+a b s\left(y_{i t-1}\right)}{2}$, where $a b s($.$) refers to the absolute value. Their measure permits negative earnings and$ retains the symmetry property of -200 percent and +200 percent.

${ }^{2}$ In results not shown, Black female volatility exhibits statistically significant pro-cyclical behavior when a time trend is not included in time-series regressions.
} 
from the middle 1980s until 2008. This rise in income volatility could be tied to social safety net policy change or stock market volatility, which should affect different skill groups.

In the bottom left panel of figure 3, earnings volatility among women with continuous employment is lower across race while maintaining the same downward trend. Upon excluding individuals transitioning into and out of the labor force, earnings volatility levels are lower for Black females than White females through the middle 1980s and the gap between the two groups' trends is diminished. Instead of observing increasing income volatility (bottom right panel) across race from 1986 onward, volatility now increases 5 percent (from 11 percent) for Black women and falls by 1 percent among White women (from a 3 percent increase after 1986). Taken together, it suggests that the inclusion of transitions from labor force entries and exits affects the Black-White difference in volatility.

\section{Heterogeneity in Volatility}

[Figure 4 here]

For a more detailed set of trends among Black women, I describe volatility by marital status and educational attainment. In the top panel of figure 4, separation occurs in the level of earnings volatility between Black females by marital status. The series for married Black females exhibits particularly high volatility between years, due to small sample sizes. In most years, single Black females have higher earnings volatility levels relative to their married counterparts and exhibit a 9 percent decline in volatility over the series compared to an overall 14 percent decline among married Black females. In the bottom panel of figure 4, volatility levels of married Whites and Blacks are lower than their single counterparts within race, but the gap is small. Single Black and White females experience an overall decline in earnings volatility of 6 and 9 percent, while married Black and White females experience a larger decline of 22 and 14 percent, respectively. For Blacks, this occurs between the early 1970s and the mid 1980s.

[Figure 5 here]

Figure 5 displays the volatility of earnings (top panel) and income (bottom panel) by education for Black females. Earnings volatility among the least skilled is highly variable between years, falls through the early 1980s, and is generally higher than that of workers with more than high school education. After 2000, year-to-year volatility among high school educated Black women spikes for the remainder of the sample period. Compared to heterogeneity by education within the overall population (ZHB), differences in volatility levels are less distinct among Black women. In 2008 there are 16 standard deviation points separating earnings volatility of all women with less than high school education to those with a high school diploma, compared to less than a point among Black females. Similar to the population as a whole, earnings volatility is generally falling for Black women, though earnings volatility for higher skilled Black women increases between 1974 and 2008.

Volatility trends for individual income (Figure 5, bottom panel) suggest similar trends with differences in levels emerging by education. Volatility of income is on the rise across education and follows the same trend since the late 1970s, with higher skill groups experiencing lower overall volatility levels. The rise in volatility occurs fastest among women with more than high school education, at 24 percent, between 1974 and 2008. Similar to earnings volatility among more than high school educated Black women, income volatility trends among the higher skilled are sensitive to choosing 1973 versus 1974 as an initial point. 


\section{Conclusion}

Among Black women, earnings volatility falls, especially throughout the 1970s and the 2000s. Meanwhile, income volatility of Black women rises from the early to middle 1980s. These volatility trends coincide with rising labor force participation of Black women, and these co-occurring trends are observed in studies pooling all women (ZHB). There is heterogeneity in volatility levels based on education and marital status, but for earnings these differences are smaller among Black women than they are in the overall population and among men. Black women and those with less education generally exhibit higher levels of income and earnings volatility, while the trends follow similar paths across race and education. In the case of earnings, racial gaps in volatility fall when the trend analysis is restricted to continuously employed women, and employment trends among highly educated women depict higher and similar levels of continuous employment across race. Given these results, it seems that differences between Black and White female volatility may be explained in part by differences in the labor market for high versus lower skilled workers and the disproportionate share of Black women without post-high school education.

To reconcile the rising income volatility and falling earnings volatility of Black females, it is worth considering the role of market volatility along with significant changes to the design and implementation of means-tested programs throughout the 1980s and 1990s (Blank 2002; Hotz and Scholz 2003; Ziliak 2009). The increasing volatility of income among Black women could be troubling if families cannot or do not smooth consumption in the event of shocks to income (Hardy 2011). Since Black women are more likely to be single, primary earners within their households, there is less reliance on a second earner to insure against economic risk. Accordingly, future research focused on understanding the welfare implications of volatility can examine the causes and consequences of income volatility for Black families, including those headed by Black women and those dependent on government transfer programs. 


\section{References}

Autor, David H., Lawrence F. Katz, and Melissa S. Kearney. 2008. “Trends in U.S. Wage Inequality: Re-Assessing the Revisionists.” Review of Economics and Statistics 90(2): 300-323.

Becker, Gary, and Nigel Tomes. 1979. "An Equilibrium Theory of the Distribution of Income and Intergenerational Mobility.” Journal of Political Economy 87(6): 1153-1189.

Betsey, Charles L. 1994. "Litigation of Employment Discrimination Under Title VII: The Case of African-American Women." American Economic Review: Papers and Proceedings 84(2): 98-102.

Blank, Rebecca. 2002. “Evaluating Welfare Reform in the U.S.” Journal of Economic Literature 40(4): 1105-1166.

Blundell, Richard, Luigi Pistaferri, and Ian Preston. 2008. "Consumption Inequality and Partial Insurance.” American Economic Review 98(5): 1887-1921.

Chaney, Cassandra, and Kris Marsh. 2009. "Factors That Facilitate Relationship Entry Among Married and Cohabiting African Americans.”' Marriage \& Family Review 45(1) : 26-51.

Chitegji, N.S., and Darrick Hamilton. 2002. "Family Connections and the Black-White Wealth Gap Among Middle-Class Families.” Review of Black Political Economy Summer 2002: 14-28.

Conrad, Cecilia. 2001. "Racial Trends in Labor Market Access and Wages: Women." In American Becoming: Racial Trends and Their Consequences. N.J. Smelser, W.J. Wilson, and F. Mitchell, eds., Washington, D.C.: National Academy Press.

Dynan, Karen E., Douglas W. Elmendorf, and Daniel E. Sichel. 2008. “The Evolution of Household Income Volatility.” http://www.brookings.edu/ /media/Files/rc/papers/2008/02_useconomics_el mendorf/02_useconomics_elmendorf.pdf

Gottschalk, Peter and Robert Moffitt. 2009. “The Rising Instability of U.S. Earnings.” Journal of Economic Perspectives 23(4): 3-24.

Gottschalk, Peter and Robert Moffitt. 1994. "The Growth of Earnings Instability in the U.S. Labor Market.” Brookings Papers on Economic Activity (1): 217-254.

Griggs v. Duke Power Co., 401 U.S. 421 (1971).

Hardy, Bradley. 2011. “Childhood Income Volatility and Adult Outcomes.” Mimeo. 
Hotz, V. Joseph, and John Karl Scholz. 2003. “The Earned Income Tax Credit.” In Means-Tested Transfer Programs in the United States, Robert Moffitt, ed., The University of Chicago Press and NBER, 141-197.

Keys, Ben. 2008. “Trends in Income and Consumption Volatility, 1970-2000.” In Income Volatility and Food Assistance in the United States, D. Jolliffe and J. P. Ziliak, eds., Kalamazoo, MI: W.E. Upjohn Institute.

Ziliak, James P., Bradley Hardy, and Christopher Bollinger. 2011. “Earnings and Income Volatility in America: Evidence from Matched CPS.” Mimeo.

Ziliak, James P. 2009. Welfare Reform and its Long Term Consequences for America's Poor. Cambridge, UK: Cambridge University Press. 


\section{Figure 1. Mean Employment Rate by Entry and Exit Status}
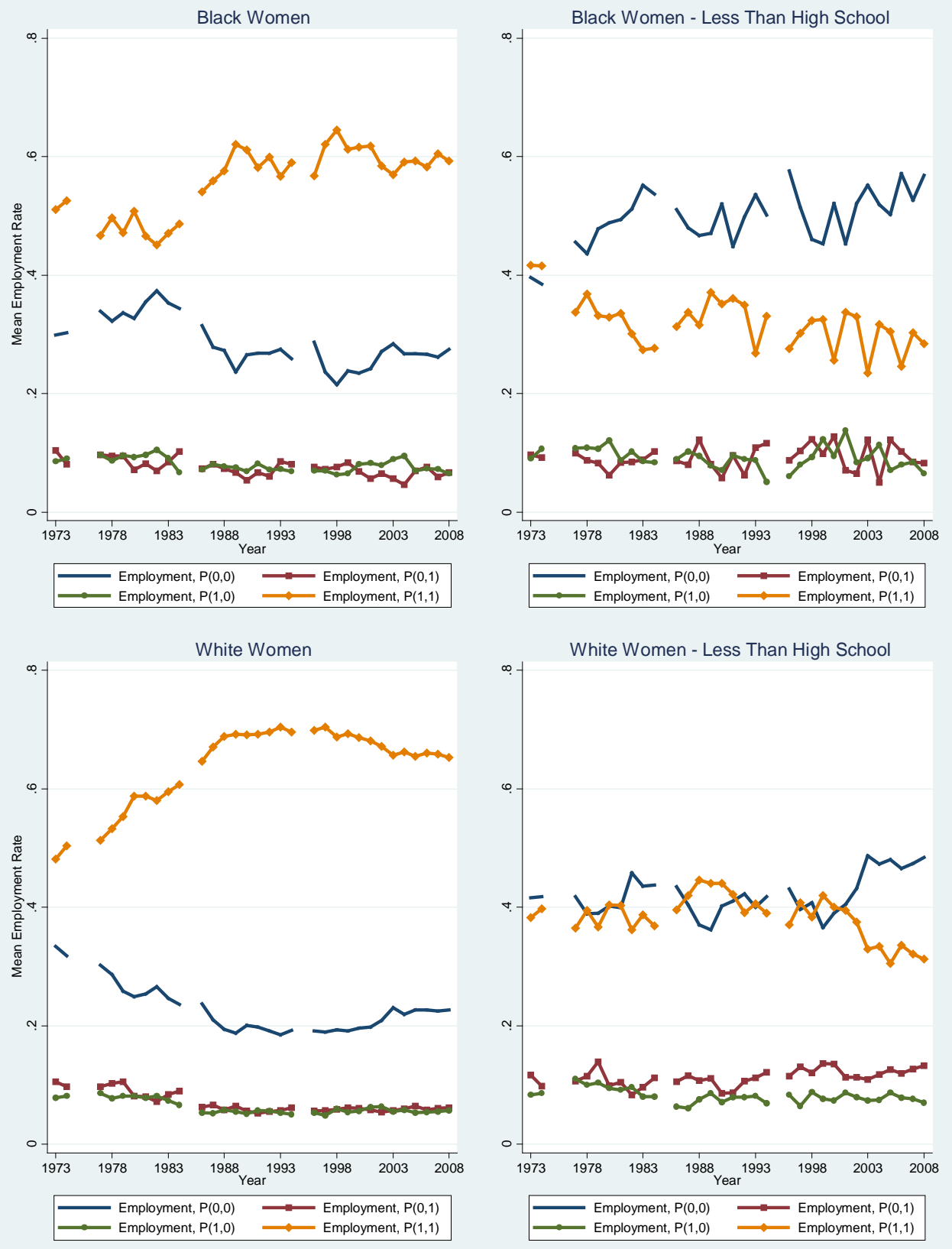
Figure 2. Mean Employment Rate by Entry and Exit Status
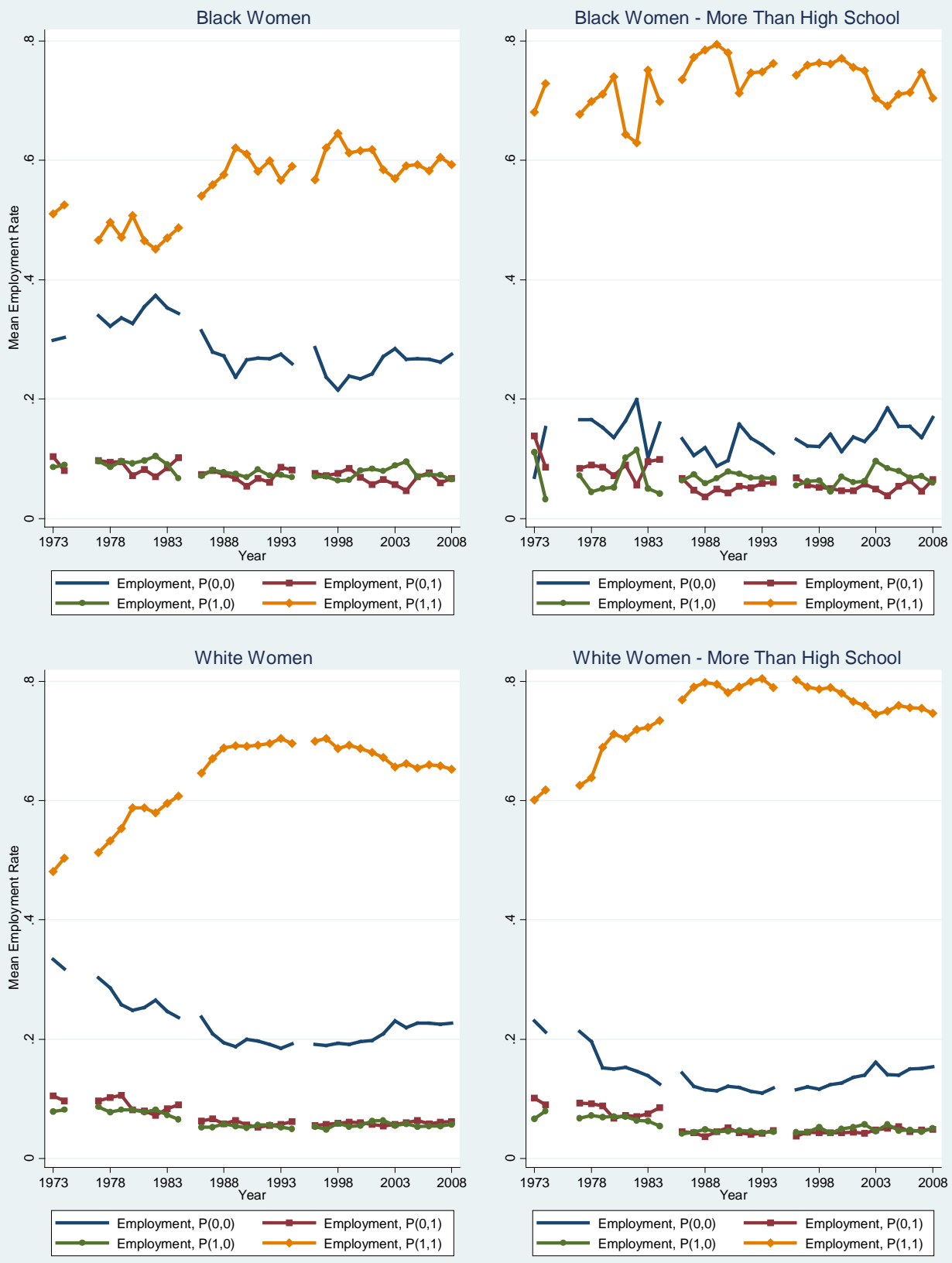


\section{Figure 3. Individual Female Volatility By Race}
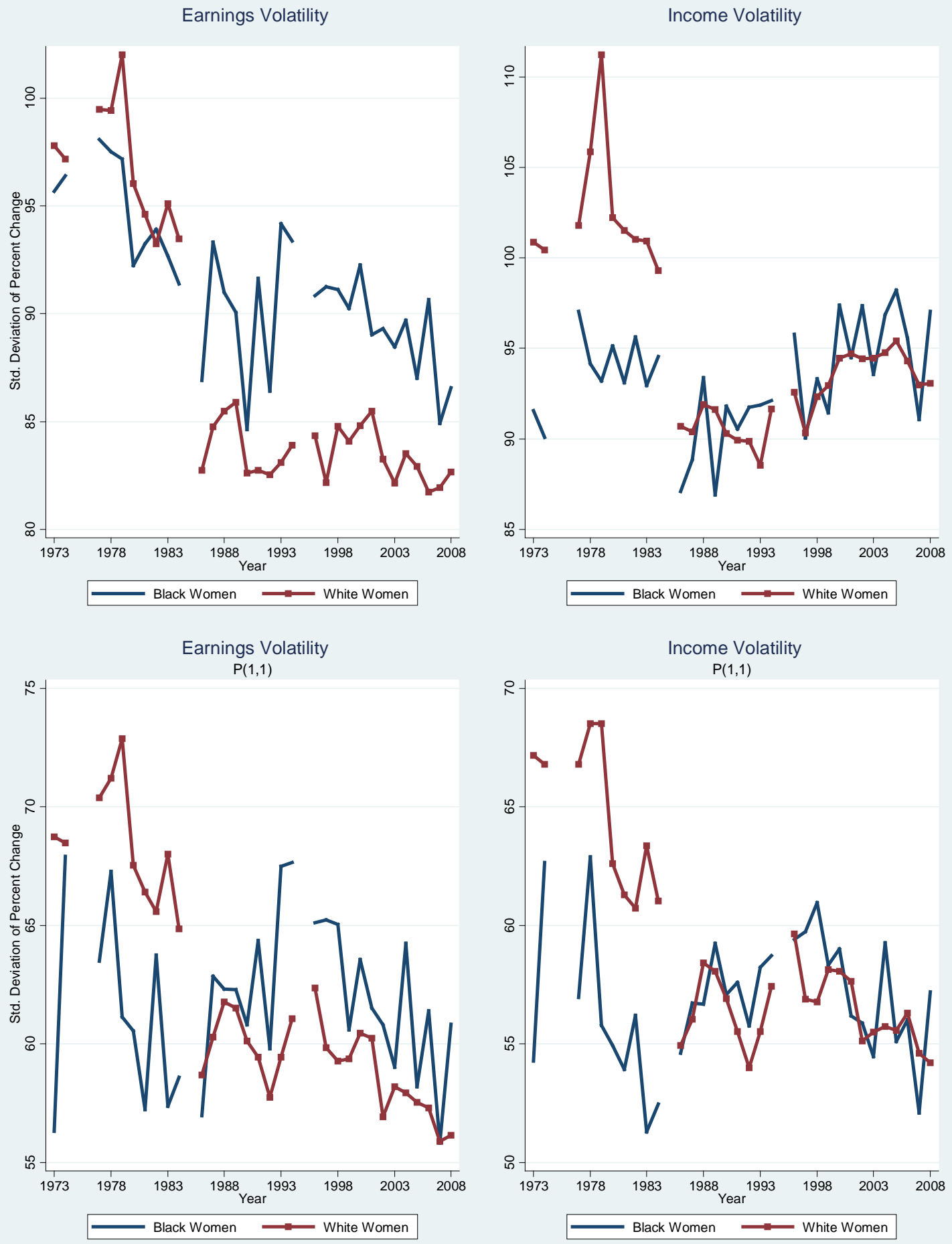


\section{Figure 4. Individual Earnings Volatility By Status in Families \& Race}

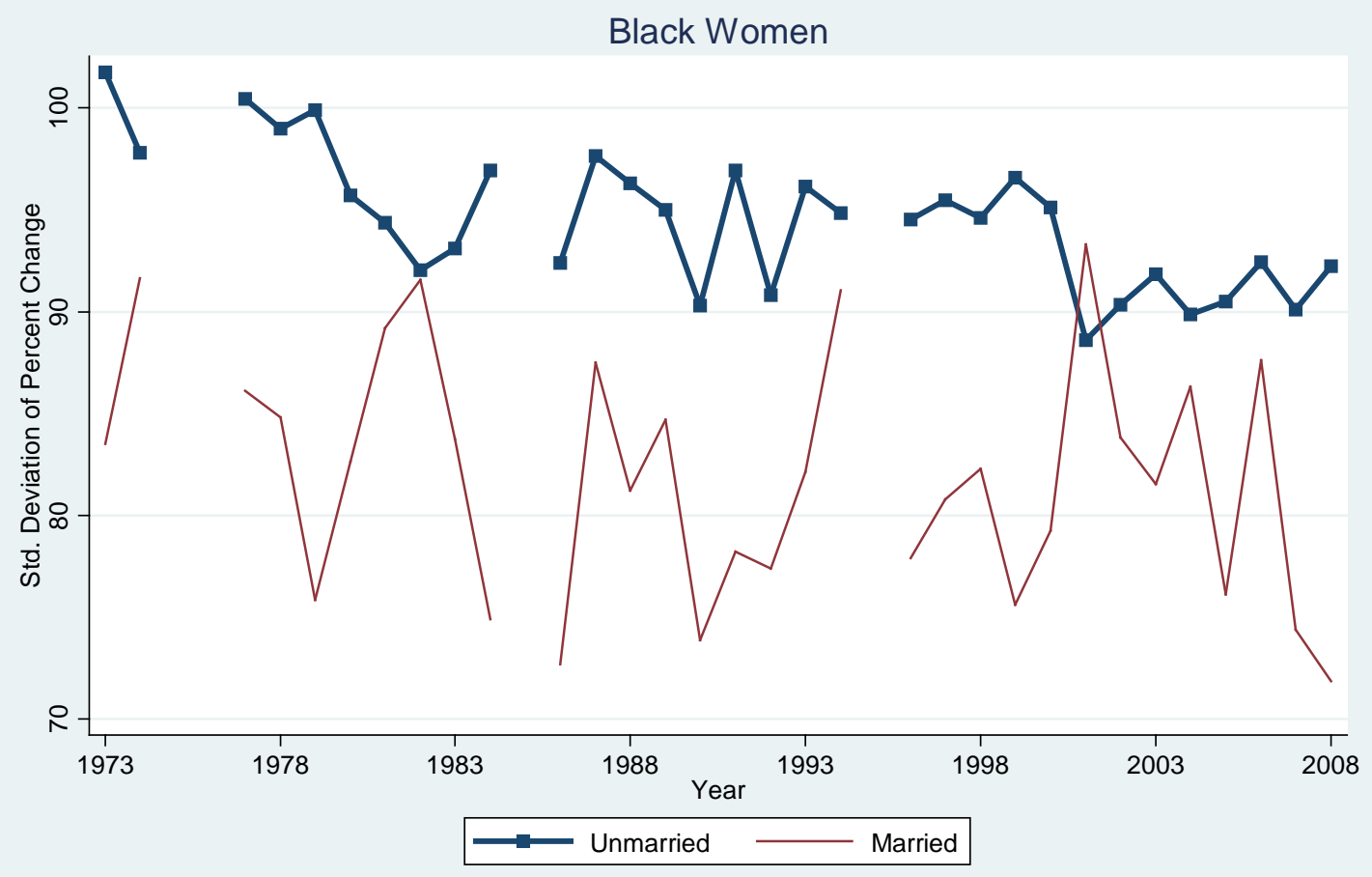

All Women

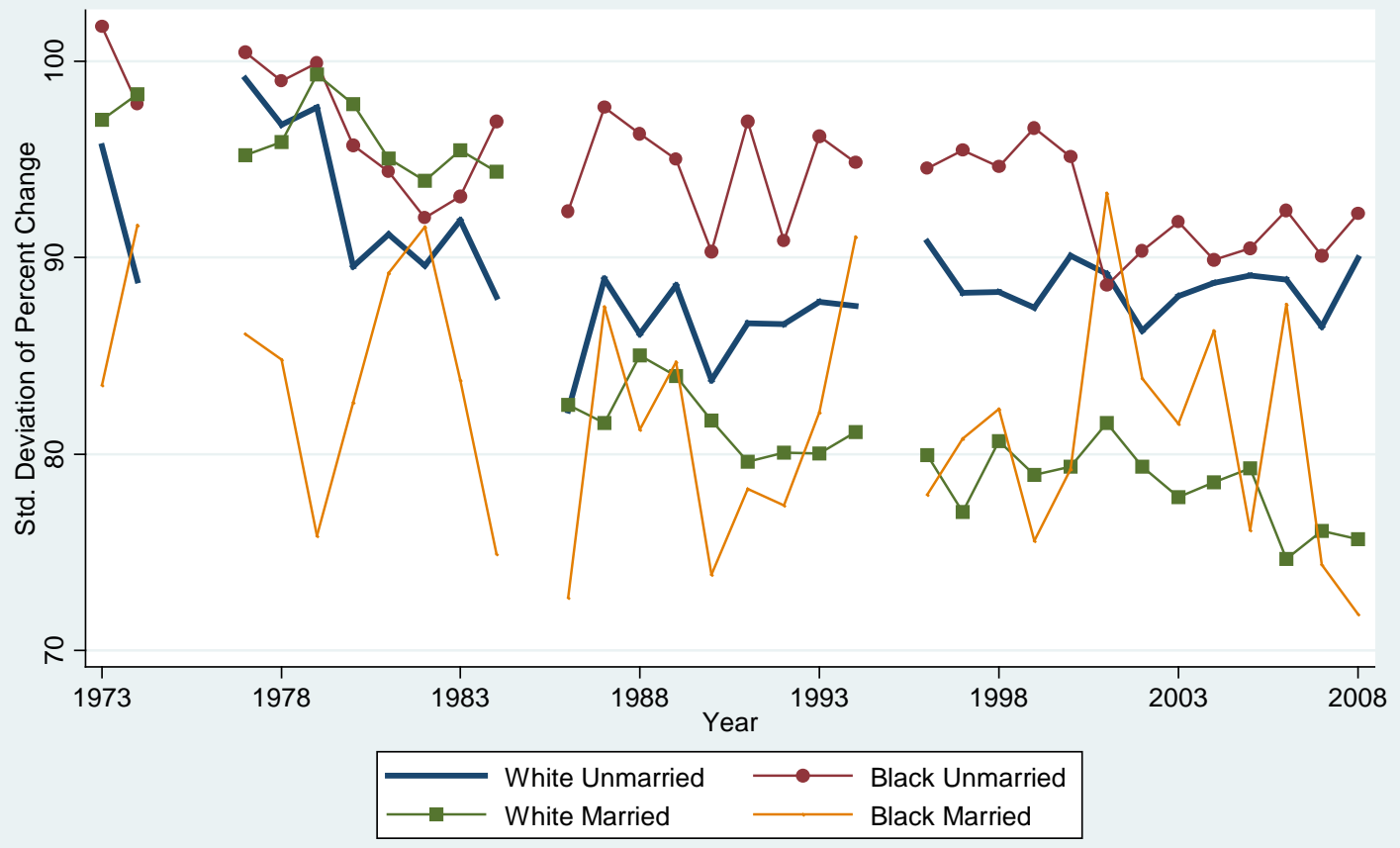




\section{Figure 5. Individual Black Female Volatility By Education}
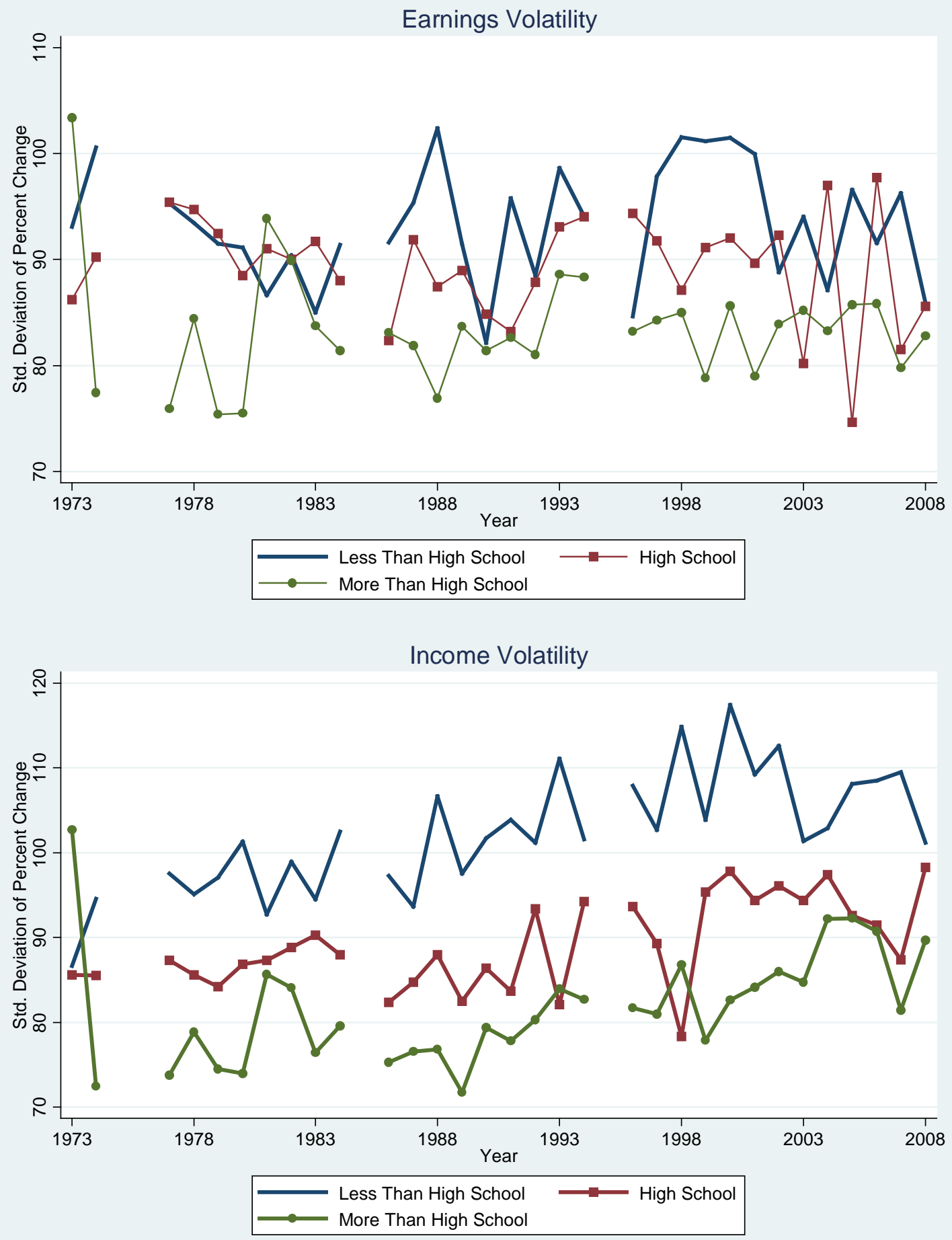
Table 1. Summary Statistics by $2^{\text {nd }}$ Year Adjusted for Inflation (2008 Dollars)

\begin{tabular}{lrrr}
\hline Variables & $\begin{array}{r}\text { Mean - } \\
\text { All }\end{array}$ & $\begin{array}{r}\text { Mean - Black } \\
\text { Females }\end{array}$ & $\begin{array}{r}\text { Mean - White } \\
\text { Females }\end{array}$ \\
& & & \\
Earnings and Income & & & \\
& & & \\
Individual Earnings (\$) & $27,481.12$ & $15,173.37$ & $17,869.86$ \\
\% Change in Individual Earnings & 5.44 & 1.78 & 6.01 \\
Individual Wage-Salary (\$) & $25,590.48$ & $14,858.80$ & $17,146.82$ \\
\% Change Individual Wage-Salary & 5.12 & 1.81 & 5.70 \\
Individual Income (\$) & $29,693.91$ & $17,555.98$ & $20,051.23$ \\
\% Change in Individual Income & 6.19 & 3.61 & 6.73 \\
& & & \\
Demographics & & & 37.98 \\
& 37.58 & 36.68 & - \\
Age & 53.54 & - & 3.26 \\
\% Female & 3.29 & 3.37 & 37.9502 \\
No. of Persons in Family & 20.52 & 30.71 & 43.81 \\
\% Less Than High School & 35.78 & 34.99 & - \\
\% High School & 43.69 & 34.30 & - \\
\% More Than High School & 86.15 & - & 66.41 \\
\% White & 9.51 & - & \\
\% Black & 4.34 & - & \\
\% Other & 62.86 & 35.99 & \\
\% Married & & & \\
& & & \\
\hline
\end{tabular}

